\title{
MAPPING DISTRIBUTION IN OKLAHOMA AND RAISING AWARENESS: PURPLE LOOSESTRIFE (LYTHRUM SALICARIA), MULTIFLORA ROSE (ROSA MULTIFLORA), AND JAPANESE HONEYSUCKLE (LONICERA JAPONICA)
}

Katherine E. Keil

Oklahoma State University

Stillwater, Oklahoma 74074

katie.keil@,okstate.edu
Karen R. Hickman

Oklahoma State University

Stillwater, Oklahoma 74074

karen.hickman@,okstate.edu

Keywords: invasive plants, management, population, fact sheet

\begin{abstract}
This paper includes updated Oklahoma distribution maps and informational fact sheets for purple loosestrife, multiflora rose, and Japanese honeysuckle to promote awareness of invasive plant issues. The current information on the Internet contains discrepancies concerning the county-level distribution data of these three invasive plants in Oklahoma. To gain a more accurate dataset, the authors created a survey and sent it to Oklahoma State University Extension Educators, Master Gardeners, Oklahoma Association of Conservation Districts, and other knowledgeable, credible parties across Oklahoma. Once survey data were compiled, 3 distribution maps were created and 6 unique fact sheets were produced with the updated information. From the 22 survey responses, 7 new county records were documented and mapped. Two new sightings were documented for purple loosestrife in Canadian County and Rogers County; 4 new sightings were documented for multiflora rose in the counties of Atoka, Johnston, Payne, and Pushmataha; and 1 new sighting was documented for Japanese honeysuckle in Garfield County. The findings in this research detail the need for updated distribution maps and increased education to prevent the spread of problem species and provide the public with methods of eradication.
\end{abstract}

\section{INTRODUCTION}

According to the United States National Arboretum, an invasive plant is a species that "has the ability to thrive and spread aggressively outside its natural range" (The United States National Arboretum 2008). These invasive plants have a competitive edge on their native counterparts because the insects, diseases, and animals that naturally keep their numbers in check do not typically exist in the new environment. This situation is known as an "enemy release", which allows the populations of an invasive species to increase to high levels, suppressing growth of native vegetation and altering their composition and structure
(Keane and Crawley 2002). Invasive plant species adversely affect the habitats they invade economically, environmentally, and/or ecologically by disrupting natural ecosystem processes (The United States National Arboretum 2008).

Purple loosestrife (Lythrum salicaria), multiflora rose (Rosa multiflora), and Japanese honeysuckle (Lonicera japonica) are 3 problematic invasive species in Oklahoma. They were chosen for this study because each represents a difference in abundance and growth form. According to the Oklahoma Vascular Plants Database (OVPD), purple loosestrife is the least abundant of the three and is known to occur in only 4 Oklahoma counties. 
Japanese honeysuckle, however, has spread extensively across Oklahoma and is listed in 45 counties. Finally, multiflora rose is documented in 39 counties (Oklahoma Vascular Plants Database 2014). The three plants also differ in growth form: purple loosestrife is an herb, multiflora rose is a shrub, and Japanese honeysuckle is a vine. Our objective was to accumulate information about invasive species that demonstrate the wide variation in abundance, growth form, and distribution of invasive plant species in Oklahoma.

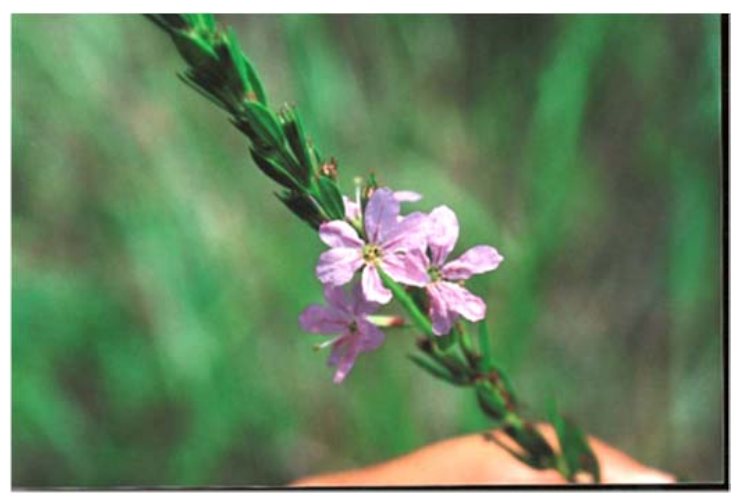

Figure 1 Purple loosestrife flower. Courtesy of Samuel Roberts Noble Foundation, Ardmore, Oklahoma.

Purple loosestrife is an erect, perennial, wetland herb that is popular among gardeners because of its magenta-colored spikes of flowers (Fig. 1) that bloom from June to September. Purple loosestrife was brought to America from Europe for ornamental and medicinal purposes in the $19^{\text {th }}$ century but was also unintentionally imported in ship ballast water (Bravo 2009a). In addition to anthropogenic vectors, the high reproductive ability of purple loosestrife has contributed to its success as an invasive species in the United States. A single flowering individual can produce approximately 2.5 million seeds a year. These seeds are dispersed by animals, humans, and other vectors that carry the propagules significant distances. For example, waterfowl can carry the seeds along waterways, or seeds can attach to boat bottoms and be transported downstream. Purple loosestrife also spreads asexually by stem and root fragments that resprout when they settle in a new location (New Hampshire Department of Environmental Services 2010). Purple loosestrife has spread extensively throughout the United States and is now documented in every contiguous state, excluding Florida (Blossey 2002).

As the Pennsylvania Department of Conservation and Natural Resources states, the rapid growth rate and resulting dense stands of purple loosestrife allow it to outcompete native vegetation, some of which may be rare or endangered species (e.g., federally endangered orchids). This causes significant ecological harm by reducing the biodiversity of an area and creating monocultures. These dense stands of purple loosestrife can reduce the native species' habitats and available food sources. Purple loosestrife can also inhibit stream flow, changing the hydrology of wetlands (Pennsylvania Department of Conservation and Natural Resources, n.d.).

Economic impacts of purple loosestrife include reduced land values for properties infested by the plant and impediment of boating and other recreational activities. In addition, purple loosestrife invades irrigation systems and adversely impacts agricultural productivity (Washington State Department of Ecology, n.d.).

However, because it is valued as a garden plant, purple loosestrife typically stirs little concern. For example, this project unveiled that purple loosestrife has been planted in demonstration and teaching gardens in Oklahoma, whose purpose is to educate the public about plants that grow well in the area (Penn State Extension 2014). Promoting invasive species growth in gardens is potentially harmful because these plants can become garden escapees, alter valuable ecosystem functions, and threaten local vegetation (The United States National Arboretum 2008). 


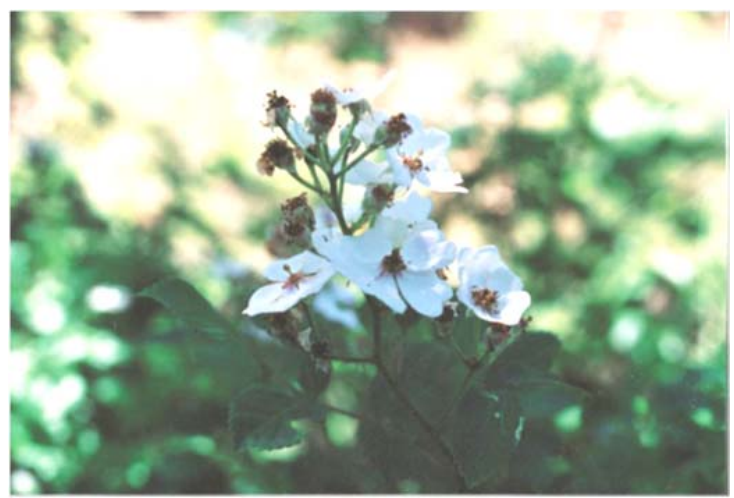

Figure 2 Multiflora rose flower. Courtesy of Samuel Roberts Noble Foundation, Ardmore, Oklahoma.

Multiflora rose is a multi-stemmed, sprawling shrub that can grow more than $4.5 \mathrm{~m}$ tall with long, arching stems that produce recurved thorns. In June and July, multiflora rose begins to bloom, displaying large clusters of fragrant white flowers (Fig. 2) (The University of Maine 2001). Multiflora rose was first introduced to the United States from Japan in 1866 as a rootstock for ornamental roses and was distributed approximately 70 years later by the U. S. Soil Conservation Service to control soil erosion. Since then, it has been intentionally spread to serve as wildlife habitat improvement, fences for livestock, vehicle crash barriers along roadways, and protection from the glare of oncoming vehicle headlights (Swearingen et al. 2010).

Even without human aid, multiflora rose is prolific and can successfully spread by its own means. Each adult plant can produce approximately 1 million seeds annually that are distributed by birds and other wildlife that eat the fruits, known as hips. Multiflora rose can also spread asexually. As stems grow taller they begin to arch, and when they come into contact with the ground they form roots (Forest Invasive Plants Resource Center 2005).

Although it is a practical shrub, multiflora rose remains highly invasive and its spread should be avoided if possible. It grows aggressively, creating dense, impenetrable thickets. These blankets of multiflora rose suppress native vegetation and lead to a loss in biological diversity by prohibiting nest construction by birds, altering habitat structure, and inhibiting forest tree regeneration (The University of Maine 2001).

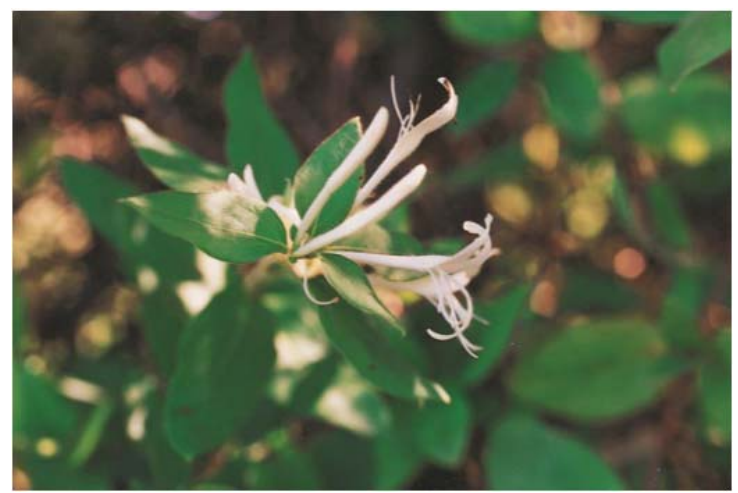

Figure 3 Japanese honeysuckle flower.

Courtesy of Samuel Roberts Noble Foundation, Ardmore, Oklahoma.

Japanese honeysuckle is a woody vine with fragrant white flowers that yellow with age. The flowers consist of 5 fused petals, occur in pairs on axillary peduncles (Fig. 3), and bloom from April to July. In autumn, mature Japanese honeysuckle plants bear small black fruits containing two to three seeds each (Forest Invasive Plants Resource Center 2005).

Japanese honeysuckle was introduced to the US from Asia in the 1800s and first became naturalized in the northeast. Since its arrival, it has been intentionally spread throughout the country because it is valued as a fragrant ornamental. Japanese honeysuckle has also been anthropogenically distributed to offset erosion and serve as wildlife forage and cover (Schierenbeck 2004). Wildlife is of further assistance to distribution by consuming Japanese honeysuckle fruits and dispersing seeds long distances (Forest Invasive Plants Resource Center 2005).

Similar to the aforementioned plants, Japanese honeysuckle is a successful invader 
without external assistance. Japanese honeysuckle's lack of natural competitors, ability to grow rapidly, adaptability to varying habitats, and prolonged growth period allow it to spread successfully. It also has vegetative runners that root when they make contact with the soil (Forest Invasive Plants Resource Center 2005).

Japanese honeysuckle impacts both individual plants and plant communities. Due to its climbing nature, Japanese honeysuckle winds around the stems and trunks of native woody plants, restricting the water flow to the plant and ultimately killing them. Japanese honeysuckle also affects the herbaceous and understory plant communities by forming a dense blanket of growth that blocks sunlight and suppresses native plants growth, altering forest structure (Bravo 2009b).

Distribution information for purple loosestrife, multiflora rose, and Japanese honeysuckle was compiled from three sources: The Oklahoma Vascular Plants Database (OVPD), The Oklahoma Invasive Plant Council (OkIPC), and The United States Department of Agriculture PLANTS Database (USDA). The OVPD is an online data source consisting of label data from specimens stored in Oklahoma herbaria. These data are queryable and are used to produce county-level distribution maps for Oklahoma plants. Since an accessioned voucher is necessary for inclusion in their database (Oklahoma Vascular Plants Database 2014), the OVPD does not accept any public observation data in the form of online submissions, photos, or other reports. The USDA PLANTS Database is a clearinghouse derived from scientific literature, herbarium specimen, and confirmed observations. The public is able to contribute by providing verifiable plant distribution information including locality, date collected, collector's name, and at least one form of documentation of the invasive plant (USDA, NRCS 2014). The OkIPC compiles data from the OVPD and observations provided by the Oklahoma Biological Survey to generate their county distribution maps. OkIPC records of invasive plants are not of exact physical locations but consist of occurrences within Oklahoma counties. Their ultimate goal is "facilitating education and management for protection of our economic and natural resources" (Oklahoma Invasive Plant Council 2014).

The county distribution maps for each plant species, however, differ between organizations, revealing discrepancies among the data sources. These differences can create confusion for Oklahomans concerned about the spread of invasive plants throughout the state. As a contribution to remedying this discrepancy, this study's objective is to update distribution data for purple loosestrife, multiflora rose, and Japanese honeysuckle and promote awareness of invasive plant impacts in 6 new fact sheets.

\section{METHODS}

We created a survey in order to more accurately reflect the distribution and density of purple loosestrife, multiflora rose, and Japanese honeysuckle in the 77 counties of Oklahoma. The survey included 11 questions about the presence, specific location, and density of these three species and was distributed to Oklahoma State University Extension Educators, Master Gardeners, Oklahoma Association of Conservation Districts, and other experienced parties across Oklahoma. Those who received the survey were encouraged to forward it to their colleagues and include it in LISTSERVs, so we estimate 250-350 surveys were distributed in total. Survey responses were recorded in an Excel ${ }^{\circledR}$ workbookfor summary and analysis. Although data were collected on the density of specific invasive plant occurrences, the resources to accurately map abundance were lacking, and thus any further conclusions on 
abundance in Oklahoma counties are excluded from this report.

These new distribution data were then compared with data from OVPD, OkIPC, and USDA. Three new maps were created to integrate the survey data with the preexisting data to enhance the accuracy of distribution maps for purple loosestrife, multiflora rose, and Japanese honeysuckle.

These maps were used in the production of two different formats of new fact sheets for each species of invasive plant. The first fact sheet follows the Oklahoma State University Extension Services format and provides a general description of the species' characteristics and life histories, invasive traits and impacts, and recommended management options (Appendix A). The second fact sheet is unique, specific to Oklahoma, and formatted to the style of an old western wanted poster. The authors designed this second fact sheet in a reader-friendly manner to attract attention and be memorable. This fact sheet includes a description of the plant and its habitat, its "crime", "hometown", classification in Oklahoma, and the number of counties in which it is found (Appendix B).

\section{RESULTS AND DISCUSSION}

The results of the data collection were limited to the 22 responses the survey respondents provided, and thus some location data on the invasive plants are less detailed than desired. A comparison of the pre-existing data from the OVPD, OkIPC, and USDA to survey data illuminates several discrepancies. Comparisons among these data sources and analysis of newly acquired data are discussed for each plant below.

\section{Purple Loosestrife}

Of the 22 surveys returned, three respondents provided data for purple loosestrife, noting that it exists in Canadian, Cleveland, and Rogers counties. In
Canadian County, purple loosestrife was sighted in the city of Edmond on Morgan Road, 0.25 miles north of Edmond Road. In Cleveland County, purple loosestrife was located in a demonstration and teaching garden in the Cleveland County Fairgrounds. In Rogers County, purple loosestrife was sighted around the edges of a homeowner's pond on the western border of the county.

The distribution maps of purple loosestrife (Fig. 4) include the OVPD occurrences in four counties and the OkIPC in 3 counties. The USDA Plants Database shows purple loosestrife as occurring in Oklahoma, but does not provide county level occurrence data. This project's data resulted in a six county distribution map with new occurrence records for Rogers and Canadian counties.

\section{Multiflora rose}

A total of 8 surveys were returned for multiflora rose, noting invasive occurrences in Atoka, Bryan, Choctaw, Comanche, Johnston, McCurtain, Oklahoma, Okmulgee, Osage, Payne, Pittsburg, and Pushmataha counties. A single respondent provided the county sightings in Atoka, Bryan, Choctaw, McCurtain, Pittsburg, and Pushmataha, describing all 6 counties as having scattered occurrences. In Comanche County, multiflora rose was sighted in the Wichita Mountains Wildlife Refuge, with the occurrence being approximately $53 \mathrm{~m}^{2}$ in size. In Johnston County, multiflora rose was sighted in the south-central part of the county, but no other information was provided. In Oklahoma County, multiflora rose was sighted on Tinker Air Force Base with the invasion being described as light to moderate in density. There were several sightings in pastures and fence lines throughout Okmulgee County. In Osage County, multiflora rose was sighted in both the southeast and far northeast portions of the county with a sparse occurrence on the ground and in fence lines. In Payne County, 
multiflora rose was sighted in a forested area outside of the Stillwater city limits and was noted as a light occurrence.

The OVPD contains records for multiflora rose for 39 counties, the OkIPC for 35 counties, and the USDA Plants Database for seven counties. Combined with this project's data, multiflora rose has a 43 county distribution with new occurrence records for Atoka, Johnston, Payne, and Pushmataha counties (Fig. 5). It is evident from the number of records of multiflora rose that this invasive plant is widespread in Oklahoma, and eradication efforts will be significantly more difficult than for purple loosestrife. Thus, efforts should be focused primarily on limiting the spread of populations to the western tier counties of Oklahoma or other uninhabited regions of the state.

\section{Japanese honeysuckle}

Nine surveys were returned on Japanese honeysuckle, providing information for Atoka, Bryan, Carter, Choctaw, Comanche, Garfield, McCurtain, Oklahoma, Okmulgee, Payne, Pushmataha, and Tulsa counties. The sightings of Atoka, Bryan, Choctaw, McCurtain, and Pushmataha counties were all recorded by one respondent, who described occurrences at "numerous locations" including the Antlers Industrial Park property, which was described as a very dense infestation. In Carter County, Japanese honeysuckle was reported as a dense occurrence on a homeowner's property east of Ardmore. In Comanche County, Japanese honeysuckle was sighted in the Wichita Mountains Wildlife Refuge, encompassing approximately $4 \mathrm{~m}^{2}$. No details were provided regarding the Japanese honeysuckle occurrences in Garfield County. In Oklahoma County, Japanese honeysuckle was sighted on Tinker Air Force Base and was described as moderately to highly dense. In Okmulgee County, Japanese honeysuckle was sighted across the county, with no specific location or density information mentioned by the respondent. In Payne County, Japanese honeysuckle was sighted in a forested area outside of Stillwater city limits and was moderately dense. In Tulsa County, Japanese honeysuckle was sighted in Mohawk Park surrounding the Tulsa Zoo.

For Japanese honeysuckle, the OVPD records this species in 45 counties, the OkIPC in 43 counties, and the USDA in 7 counties. In combination with this project's data, Japanese honeysuckle has a 46 county distribution with a new occurrence record for Garfield County (Fig. 6). Japanese honeysuckle is not present in the northwestern portion of Oklahoma, which is likely due to colder temperatures and lower precipitation that limits Japanese honeysuckle growth (Forest Invasive Plants Resource Center 2005). However, the rest of the state is widely inhabited by this species and thus efforts should be focused on preventing further spread of this highly invasive plant in these areas.

\section{Distribution maps}

The differences in county distributions among the OVPD, OkIPC, and USDA, (see Figs. 4-6) can be attributed mostly to each organization's differing data sources. The USDA Plants Database distribution maps had the lowest documented occurrences of these species, while the OVPD had the most occurrences recorded.

It is important to note that not all invasive occurrences are equally significant. For example, the record of purple loosestrife in the Cleveland County demonstration gardens may hold less threat of spreading beyond the residential site; whereas, the invasion on the pond's edge in Rogers County is more problematic due to its increased likelihood of spreading through the watershed. Purple loosestrife is readily transported through waterways, establishing communities downstream or in this example, potentially spreading around the 


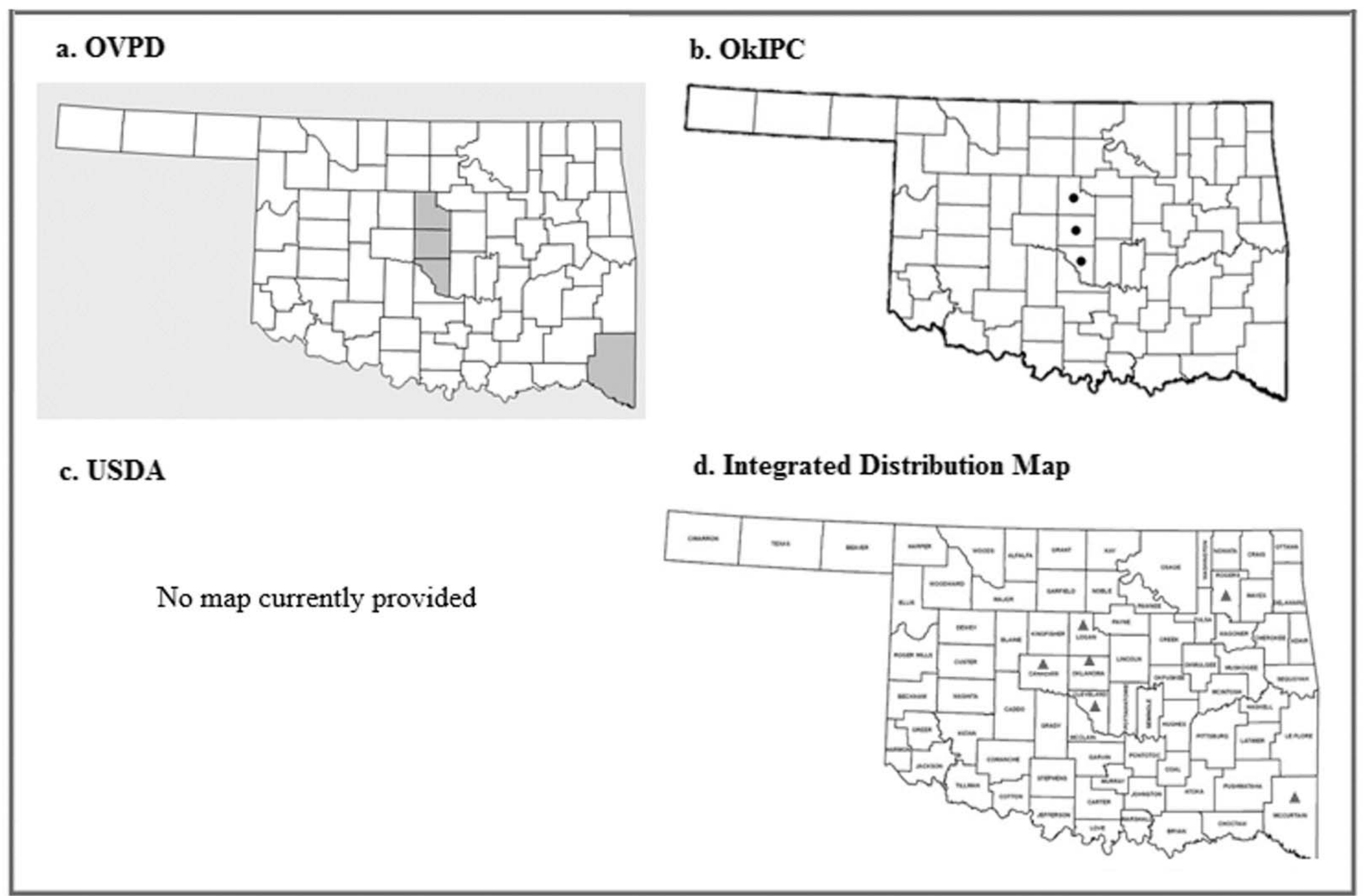

Figure 4 The distribution of purple loosestrife in Oklahoma between sources 


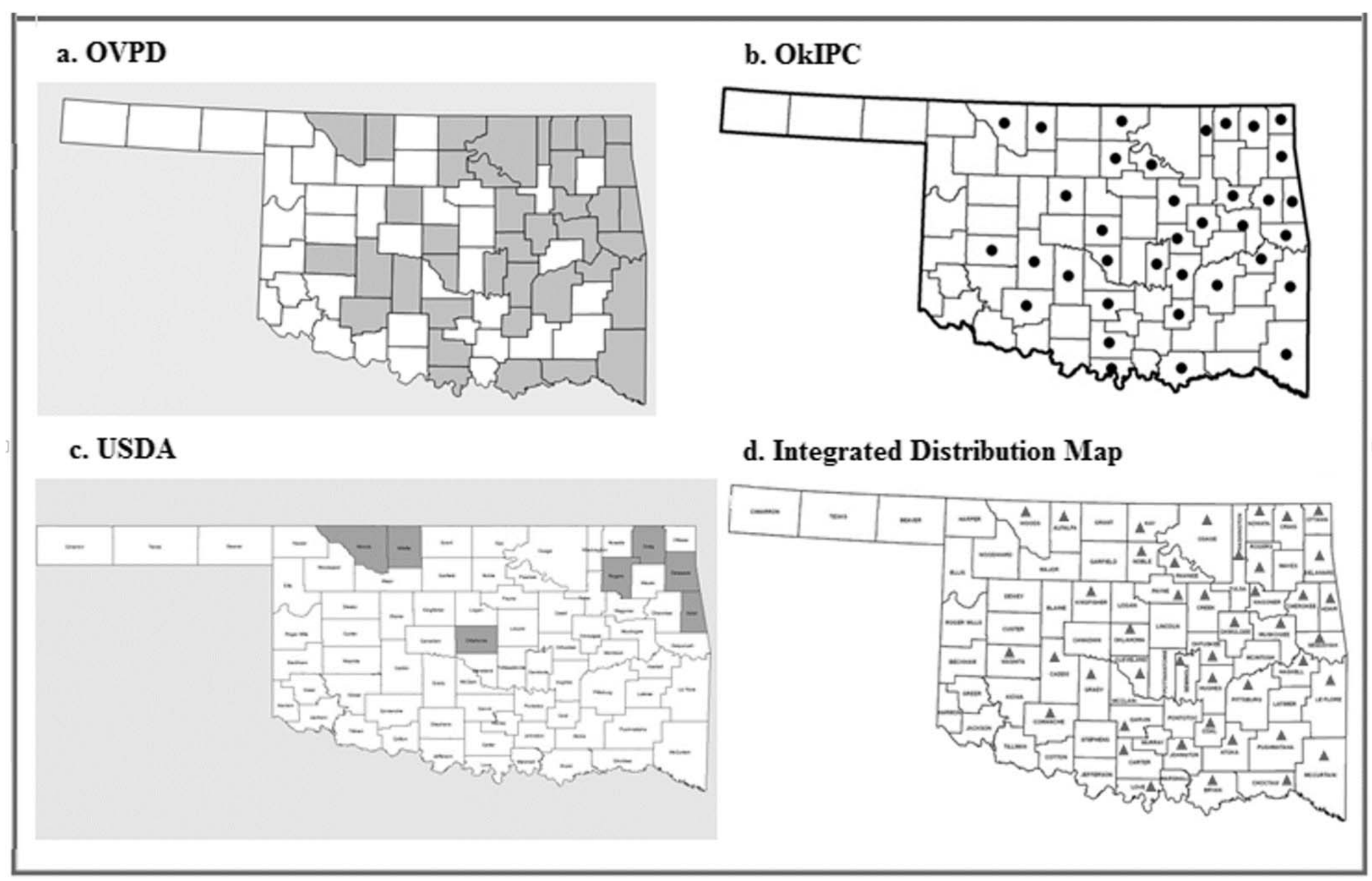

Figure 5 The distribution of multiflora rose in Oklahoma between sources 


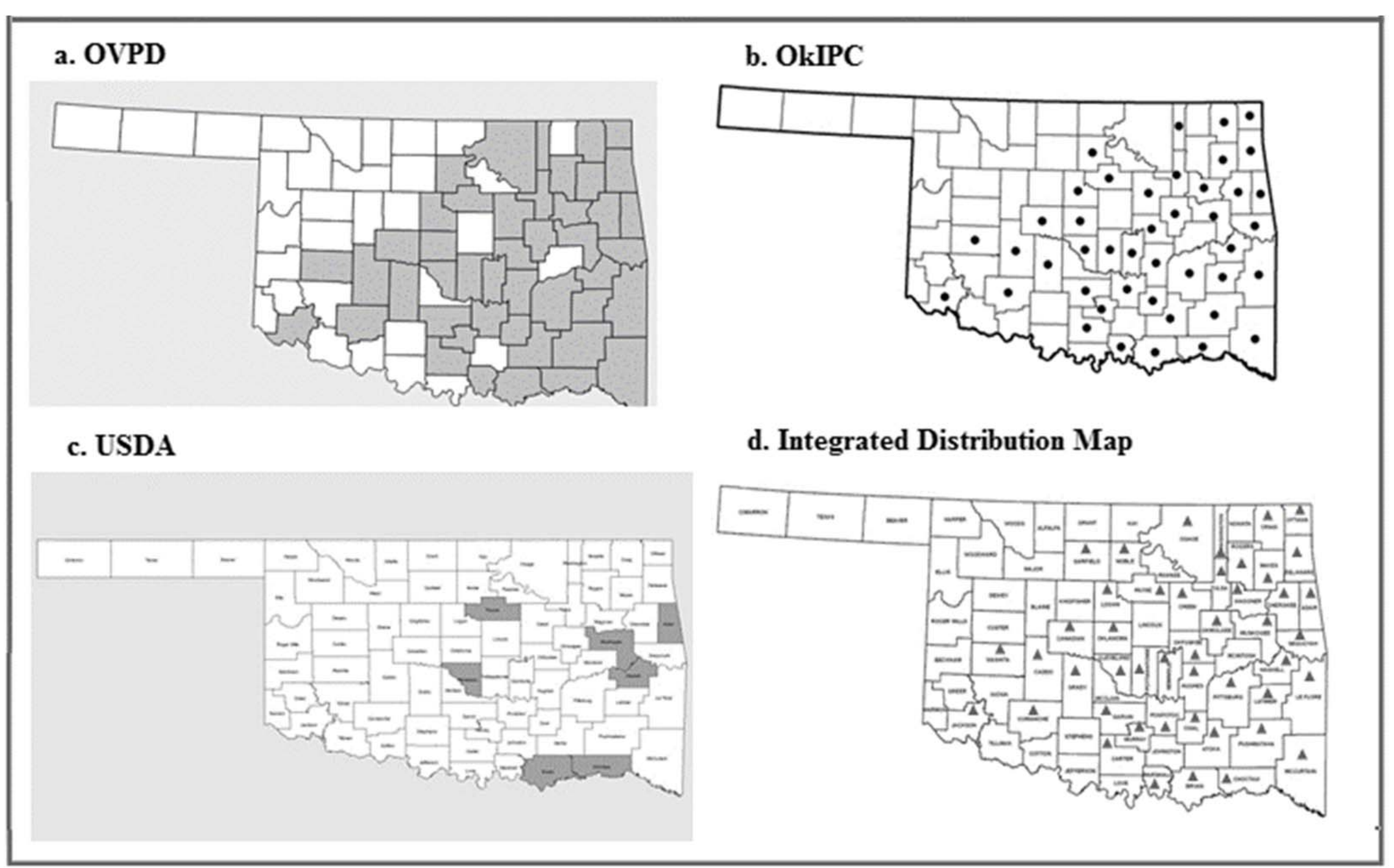

Figure 6 The distribution of Japanese honeysuckle in Oklahoma between sources 
Rogers County pond. Once established, these purple loosestrife stands may outcompete the native vegetation and alter the pond's wetland structure and function (New Hampshire Department of Environmental Services 2010). In addition, these larger communities of purple loosestrife have increased odds of spreading to other sites due to the greater number of offspring they produce. In the Cleveland County gardens, however, the extent of the purple loosestrife population may be maintained, and there is reduced opportunity to spread through the waterways. The difference in each organization's criteria for adding an invasive into their distribution maps may explain why the ornamental planting in the Cleveland County gardens is not listed by any of the organizations. The authors, however, have included the Cleveland County record in this report to show that residential ornamental plantings, albeit less pervasive than others, can still spread outside the garden's borders and cause ecological impact. Although it may not qualify as a record by the organizations listed in this report, it can be argued that no invasive plant should be viewed as acceptable and remain undocumented.

Overall, accurate distribution maps must be produced to inform the public and land managers where invasive populations exist in order to limit the spread of invasive populations to uninhabited areas of Oklahoma. Accurate fact sheets must also be available to guide conservationists to the best method(s) for their eradication.

\section{CONCLUSION}

The objective of this study was to emphasize the need for more research in invasive plant distributions while increasing the number of known occurrences for purple loosestrife, multiflora rose, and Japanese honeysuckle using survey responses. Based on survey results, 7 new county-level occurrences were documented for these 3 invasive plants. The differences among existing data sources in this report currently provide conflicting impressions of invasive plant distributions. These discrepancies can potentially impede management and eradication efforts and become increasingly problematic without the availability of accurate data.

It is evident that one person or research project alone cannot efficiently take on the burden of mapping invasive plants. Invasive plant species play a role in many aspects of life - from the environment to the economy - and must be considered as a group. Programs such as Early Detection and Distribution Mapping System (EDDmapS $囚)$, a phone application and website, enable the citizen scientist aspect of research. This program allows a user to upload photographs, GPS coordinates, and population data of a plant that they believe is invasive. These data are then submitted to an expert to confirm species identification. Once the identification is verified, the occurrence is added to a statewide distribution map that is viewable online (EDDMapS 2014). Maps that contain more detailed occurrence records enhance our ability to provide information to the public about the threats these invasive species have on our natural resources.

\section{ACKNOWLEDGMENTS}

We would like to thank Tracey Miller for helping distribute the survey. We also appreciate the respondents, all of whom provided significant assistance in this project: Chad Webb, Greg Highfill, Will Cubbage, Pearl Pearson, Dennis Martin, Scott Johnson, Loren Sizelove, Doug Maxey, Paul Koenig, Tracey Miller, Ray Ridlen, Tom Smith, Mindy McNair, Jay Ross, Danny Cook, John Hasse, John Krupovage, Todd Fagin, Mike Porter, Jim Johnson, and Jeanetta Cooper. 


\section{LITERATURE CITED}

Blossey, B. 2002. Purple Loosestrife. Ecology and Management of Invasive Plants Program. http://www.invasiveplants.net/plants/p urpleloosestrife.htm. Accessed 20 April 2014.

Bravo, M.A. 2009a. Purple Loosestrife. Plant Conservation Alliance. National Park Service. http://www.nps.gov/plants/alien/fact/ loja1.html. Accessed 15 April 2014.

Bravo, M.A. 2009b. Japanese Honeysuckle. Plant Conservation Alliance. National Park Service. http://www.nps.gov/plants/alien/fact/ loja1.htm. Accessed 15 April 2014.

EDDMapS. 2014. Early Detection \& Distribution Mapping System. The University of Georgia - Center for Invasive Species and Ecosystem Health. Available online at http://www.eddmaps.org/; last accessed December 30, 2014.

Forest Invasive Plants Resource Center. 2005. USDA Forest Service. na.fs.fed.us/spfo/invasiveplants/index.a sp. Accessed 15 April 2014.

Keane, R.M.and M.J. Crawley. 2002. Exotic plant invasions and the enemy release hypothesis. Trends in Ecology and Evolution 17:164-170.

Maryland Department of Natural Resources. n.d. Facts about Purple Loosestrife. http://dnr.maryland.gov/wildlife/plants wildlife/purpleloosestrife/index.asp. Accessed 19 April 2014.

New Hampshire Department of Environmental Services. 2010. Purple Loosestrife: An Exotic Menace. http://des.nh.gov/organization/commi ssioner/pip/factsheets/bb/documents/ bb-45.pdf. Accessed 10 April 2014.

Oklahoma Invasive Plant Council. n.d. Oklahoma's Problem Species. http://ok-invasive-plant- council.org/species.html, Accessed 20 March 2014.

Oklahoma Vascular Plants Database. n.d. Oklahoma Biological Survey. University of Oklahoma, Norman. http://www.oklahomaplantdatabase.org. Accessed 3 February 2014.

Penn State Extension. 2014. Demonstration Gardens. http://extension.psu.edu/plants/mastergardener/counties/allegheny/demonstrat ion-gardens. Accessed 19 November 2014.

Pennsylvania Department of Conservation and Natural Resources. n.d. Invasive Plants in Pennsylvania Purple Loosestrife. http://www.dcnr.state.pa.us/cs/groups Lpublic/documents/document/denr 0 10234.pdf. Accessed 19 November 2014.

Shierenbeck, K. 2004. Japanese Honeysuckle (Lonicera japonica) as an invasive species: History, ecology, and context. Critical Reviews in Plant Sciences 23:391-400.

Swearingen, J., B. Slattery, K. Reshetiloff, and S. Zwicker. 2010. Plant Invaders of Mid-Atlantic Natural Areas. $4^{\text {th }}$ ed. The National Park Service, U.S. Fish and Wildlife Service. Pg. 69-70.

The United States National Arboretum. 2008. Invasive Plants. http://www.usna.usda.gov/Gardens/in vasives.html. Accessed 25 April 2014.

The University of Maine. 2001. Maine Invasive Plants. http://umaine.edu/publications/2509e. Accessed 1 May 2014.

USDA, NRCS. 2014. The PLANTS Database. http://plants.usda.gov. Accessed 26 July 2014.

Washington State Department of Ecology. n.d. Non-Native Invasive Freshwater Plants. http://www.ecy.wa.gov/programs/wq/ plants/weeds/aqua009.html. Accessed 1 May 2014. 


\section{APPENDIX A}

\section{Fact Sheet: Purple Loosestrife}

Common Name: Purple Loosestrife

Scientific Name: Lythrum salicaria

Country of Origin: Europe and Asia

History of Introduction: It was brought to North America and Canada in the early 1800s from Eurasia for ornamental and medicinal purposes. It was also imported accidentally as a contaminant on ship ballasts or as seeds on raw wool and sheep aboard. When the US expanded their road and canal systems, purple loosestrife expanded with these developments and now inhabits every contiguous state in the nation except Florida.

How It Invades: Purple loosestrife spreads by seeds, which an adult plant produces about 2.5 million a year. Purple loosestrife is also able to spread by re-sprouting from roots and fragments. It is easily transported by animals, waterways, boats, cars, and many other vectors.

Species Description: Purple loosestrife is an erect perennial herb that stands typically 3-10 feet tall. It has showy magenta colored flower spikes consisting of 5-7 petals that bloom from July to September. The flower has a yellow-white center that contains nectar and is useful for bee-forage. Purple loosestrife has tough stems, which can number as many as 50. Its leaves are lance-shaped and heartshaped or rounded at the base with pubescent surfaces.

Population Level Traits Promoting Invasion: Purple loosestrife is able to invade native communities successfully because it is able to adapt quickly, produces a large amount of offspring, thrives in a wide variety of wet habitats and conditions, has no natural predators, and spreads rapidly.

Community and Ecosystem Level Effects of Invasion: Purple loosestrife is problematic because it outcompetes native vegetation creating monocultures, changes water flow that can cause sediment buildups, alters the nitrogen cycle and the water's chemistry, grows in irrigation systems which blocks the flow of water, alters wetland structure and thus function, and forms dense stands which reduces native animals habitat and food sources.

Management: Purple loosestrife can be managed through mechanical, chemical, and biological methods. If a small community exists, physically remove the plants and (if possible) burn them. For larger communities, spray with a glyphosate herbicide and/or use the beetle Galerucella spp. that feeds on the purple loosestrife. Ideal time for removal is in June-September due to plant's noticeability and lack of seeds.

\section{References:}

1.) http://des.nh.gov/organization/commissioner/pip/factsheets/bb/documents/bb-45.pdf

2.) http://www.nps.gov/plants/alien/fact/lysa1.htm

3.) http://www.invasiveplants.net/plants/purpleloosestrife.htm

4.) http://dnr.maryland.gov/wildlife/plants wildlife/purpleloosestrife/index.asp

5.) http://plants.usda.gov/plantguide/pdf/pg lysa2.pdf 


\section{Fact Sheet: Multiflora Rose}

Common Name: Multiflora rose

Scientific Name: Rosa multiflora

Country of Origin: Japan, Korea, and Eastern China

History of Introduction: Multiflora rose was introduced to the United States from Japan in 1866 as a rootstock for grafted ornamental cultivars. In the 1930s, it was further distributed by the U.S. Soil Conservation Service to control erosion. It also has been promoted as effective habitat for animals, crash barriers and headlight reduction for roadways, and fencing for livestock. Multiflora rose has since spread significantly and now encompasses 30 states, including the D.C. area.

How It Invades: Multiflora rose most commonly establishes from fruits that fall close to the original plant, which lead to dense thickets. However, animals that eat the plant can disperse seeds longer distances. A single adult plant can produce 1 million seeds annually. Plants can also establish roots where their canes touch the ground.

Species Description: Multiflora rose is a perennial thorny shrub that can grow to upwards of 15 feet tall. It has clusters of white or tinted pink flowers consisting of 5 petals that appear in May or June. It is multi-stemmed with long, flexible stems containing re-curved thorns and large, alternate leaves. Multiflora rose can sometimes be a climbing vine.

Population Level Traits Promoting Invasion: Multiflora rose is able to invade native communities successfully because it has a tolerance for diverse soil conditions, grows aggressively, and produces a lot of offspring. It also has a long-lived seed bank that remains viable for 10-20 years that allows it to invade communities even after it is believed to be eradicated.

Community and Ecosystem Level Effects of Invasion: It forms dense, impenetrable thickets that outcompetes native vegetation for resources, including light.

Management: Mechanical, chemical, and biological methods can be implemented to manage multiflora rose. Cutting and hand-pulling can remove plants, but one must ensure that all roots are removed in order to be successful. Frequent cuttings of 3-6 times a growing season may be necessary. Glyphosate herbicides can be sprayed on the foliage or applied to stumps and is ideally used during the dormant season to minimize effect on native plants. Rose-rosette disease, a virus, is transported by mites and has fatal effects on multiflora rose. It can kill plants in two years, but must be used with caution so that it does not also wipe out native plants. Goats and other grazers can also aid in the control of multiflora rose. Fire regimes can prevent plant establishment as well.

\section{References:}

1.) http://www.nyis.info/index.php?action=invasive detail\&id=33

2.) http://www.nps.gov/plants/alien/fact/romu1.htm

3.) http://mdc.mo.gov/your-property/problem-plants-and-animals/invasive-plants/multiflora-rose-control 


\section{Fact Sheet: Japanese Honeysuckle}

Common Name: Japanese Honeysuckle

Scientific Name: Lonicera japonica

Country of Origin: Japan and Korea

History of Introduction: Japanese honeysuckle was introduced to Long Island, New York from Japan in 1806 for ornamental and ground cover purposes. It was slow to spread, but once it escaped New York it took over the majority of the United States by the early 1900s. It has since been used for erosion control and wildlife forage and cover.

How It Invades: Japanese honeysuckle invades ecosystems through a series of long runners that develop roots and underground rhizomes. Their seeds can also be transported by birds and other wildlife that consume the berries.

Species Description: Japanese honeysuckle is a perennial woody vine that often remains evergreen. Its white flowers contain 5 petals and bloom from April to October, turning yellow with age. These flowers occur in pairs at leaf junctures and are highly fragrant. Japanese honeysuckle is notorious for twisting around objects, specifically stems and trunks. Small, black fruits form in August.

Population Level Traits Promoting Invasion: Japanese honeysuckle is able to invade native communities successfully because it has few natural enemies in North America, is tolerant to a wide range of environmental conditions, spreads by sending out vegetative runners that can root in a plethora of environments, forms dense thickets, and has a high growth rate. It also has a large seed bank, which can remain viable in the soil for long periods of time.

Community and Ecosystem Level Effects of Invasion: Japanese honeysuckle inflicts damage on forest communities because it twines around stems and trunks, establishing dense blankets that block out light, inhibit water flow in native plants, and ultimately smother them. It can prevent growth of native vegetation and decreases the biological diversity of the area. Because Japanese honeysuckle largely remains evergreen, it remains physiologically active while other vegetation is dormant, allowing it to outcompete native plants.

Management: Prevention is ideal, but both mechanical and chemical management options exist if Japanese honeysuckle becomes established. For small communities, hand-pulling at the base of the plant to uproot it and cutting the vines can be successful if monitored regularly to ensure no new seedlings have established. Mowing in both July and September can be beneficial for larger patches. Glyphosate herbicides can be applied in autumn when the plant has healthy, green leaves, but should be carefully applied according to labels. Burning can eliminate the ground cover, but since Japanese honeysuckle contains underground rhizomes, prescribed burns remain a temporary solution. Finally, animals such as goats have been successful in eating this invasive plant and preventing further spread of it. A combination of the practices listed above will be most effective.

\section{References:}

1.) http://www.nps.gov/plants/alien/fact/loja1.htm

2.)Error! Hyperlink reference not valid. $\mathrm{http}: / / \mathrm{mdc}$.mo.gov/your-property/problem-plants-andanimals/invasive-plants/japanese-honeysuckle-control

3.) http://www.in.gov/dnr/files/Japanese Honeysuckle.pdf

4.) http://plants.ifas.ufl.edu/node/239 


\section{APPENDIX B}

Wanted Poster Fact Sheet: Purple Loosestrife

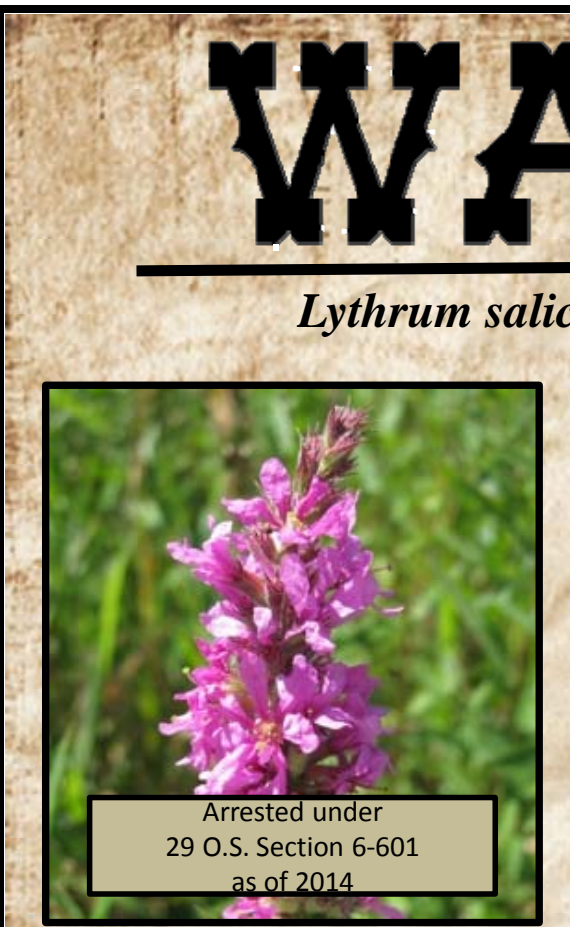

Description: 3-10 feet tall perennial herb Magenta colored flower spikes consisting of 5-7 petals from July to September, often has multiple tough stems, leaves are lance-shaped and heart-shaped or rounded at the base

Hometown: Europe

Oklahoma Classification: Declared aquatic nuisance species

Habitat: Wetland conditions (i.e., marshes, river banks, ditches, pond edges, roadsides, reservoirs, and wet meadows)

Crime: Suppression of native vegetation leading to loss of biological diversity, alteration of $\mathrm{N}$ cycle and flow of water, disruption of natural wetland function, elimination of food sources for animals

Instructions for "Capture": If small community, manually remove plant and (if possible) burn it. For larger communities, spray with a glyphosate herbicide or use the beetle Galerucella spp.

Ideal time for removal is in June-August due to plant's noticeability

Sightings: Approximately 6 counties in Oklahoma

Victims: Unsuspecting wetlands or waterways

How you can help: Prevent it, Recognize it, Report it, and Remove it

Citations: http://www.nps.gov/plants/alien/fact/pdf/lysa1.pdf http://www.dnr.state.mn.us/invasives/aquaticplants/púrpleloosestrife/control.html http://www.sleloinvasives.org/about-invasives/target-species/purple-loosestrife/ 


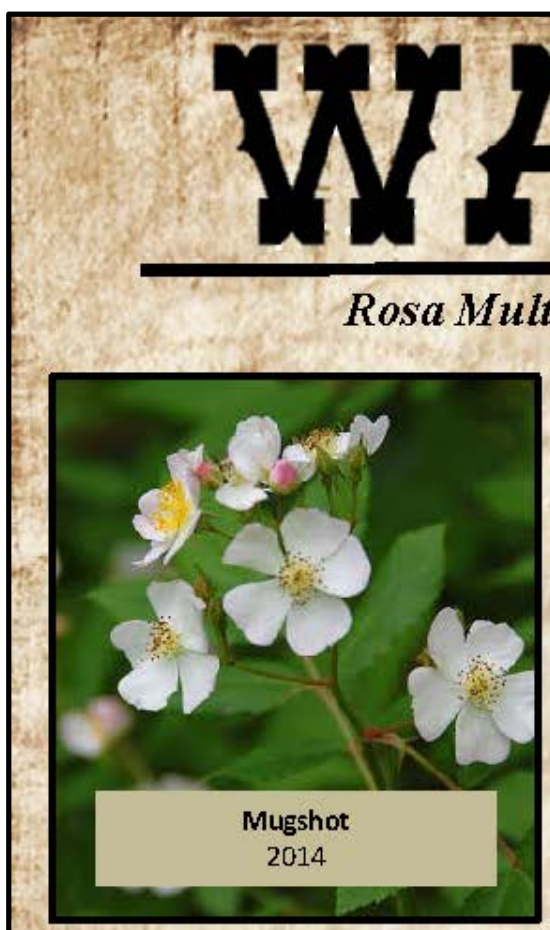

Description: Up to 15 feet tall thorny shrub, Clusters of white or tinted pink flowers with 5 petals in May and June, Multi-stemmed with long flexible stems, leaves are alternate with large oval leaflets

Hometown: Japan, E. China, Korea

Oklahoma Classification: No current legal status

Habitat: Sunny areas with well drained soil but can survive a range of conditions (i.e., stream banks, forests, prairies, woodlands, and wetlands)

Crime: Suppression of native vegetation leading to loss of biological diversity, alteration habitat structure which prohibits nesting of birds, creates impenetrable thickets

Instructions for "Capture": If a small community, manually mow or cut plants. For larger communities, spray with a herbicide, promote grazing by sheep and goats, or use the mite Phyllocoptes fructiphilus

Monitoring and control required for several years

Sightings: Approximately 43 counties in Oklahoma

Victims: Unsuspecting native herbs and shrubs

How you can help: Prevent it, Recognize it, Report it, and Remove it

\section{Citations:}

http://www.fs.fed.us/database/feis/plants/shrub/rosmul/all.html\#managementconsiderations http://na.fs.fed.us/spfo/invasiveplants/factsheets/pdf/multiflora-rose.pdf

http://contentinac ottage.blog spot.com/20120/05/wildflowers-common-fl eaband-and.html
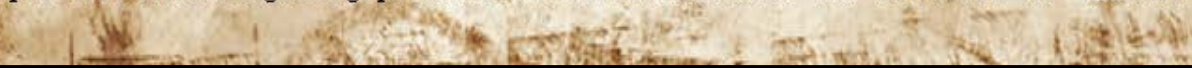

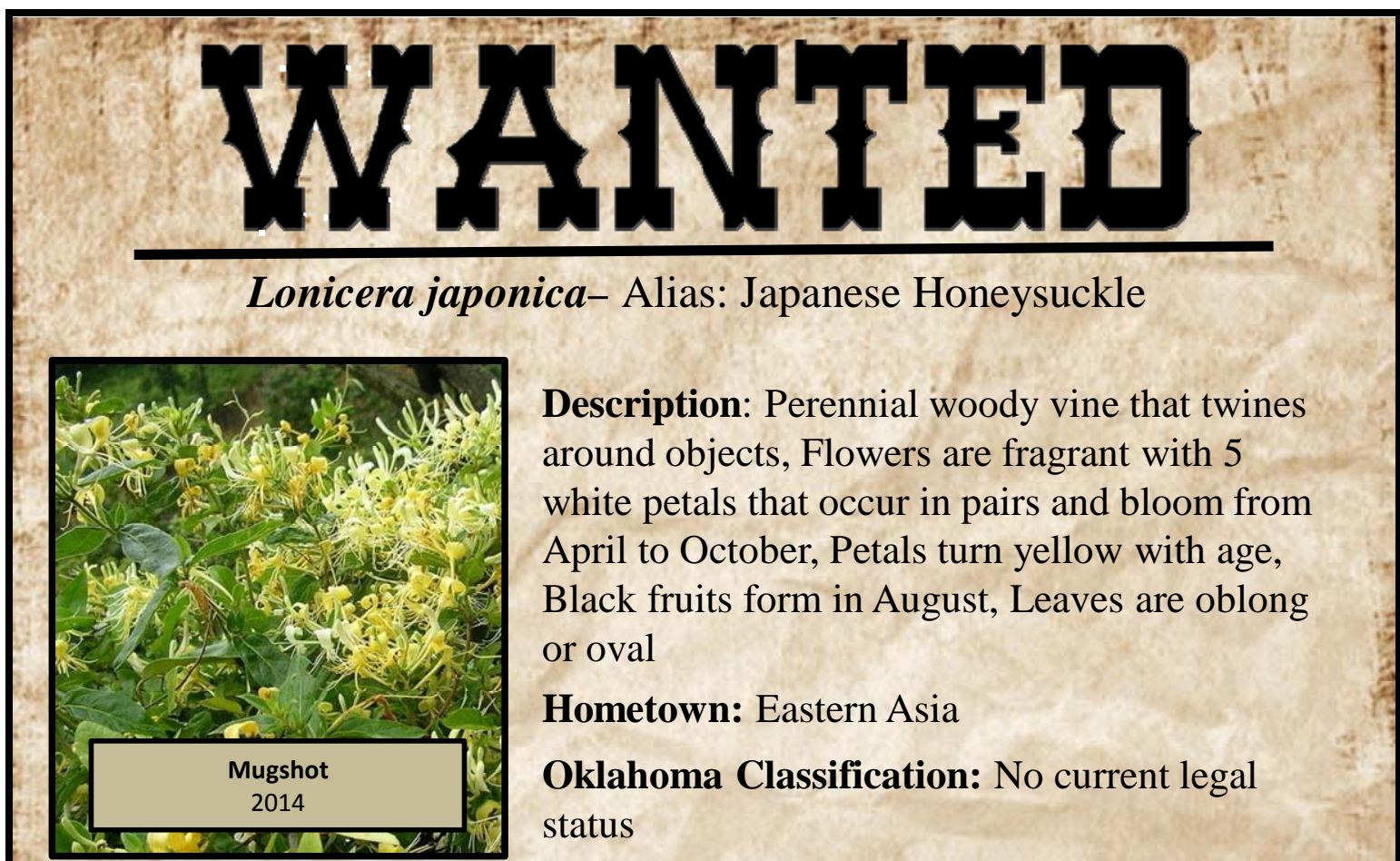

Habitat: Open natural communities, but can thrive in a wide range of environmental conditions (i.e., successional fields, old home sites, forests)

Crime: Suppression of native vegetation by forming dense blankets, alteration of forest structure, encircling of trees and stems which cuts off water flow to plant

Instructions for "Capture”: For small communities, hand-pulling the entire plant and mowing can be effective. For larger communities, applying a glyphosate herbicide when green leaves are present is recommended.

Sightings: Approximately 46 counties in Oklahoma

Victims: Unsuspecting native herbs and shrubs

How you can help: Prevent it, Recognize it, Report it, and Remove it

Citations: http://plants.ifas.ufl.edu/parks/japanese_honeysuckle.html http://www.nps.gov/plants/alien/fact/loja1.htm

http://www.cnseed.org/japanese-honeysuckle-seeds-lonicera-japonica-seeds.html 